\title{
Granger Causality Analysis of Shariah Banking Deposit to Conventional Banking Deposit
}

\author{
Isbandini Veterina \\ Indonesia Banking School \\ isbandini.veterina@ibs.ac.id
}

\begin{abstract}
Countries with a dual banking system always question the independence of Islamic Bank on conventional bank. Although theoretically there are basic differences between Islamic bank with its profit loss sharing principle and the conventional bank with its interest rate system, but still, is the return that Islamic banks give to their customer is purely based on the bank's performance? There is always a question that the Islamic Bank system are benchmarking their return rate against the conventional Bank's interest system. This research purpose is to test the independence of Islamic commercial bank from conventional commercial bank in Indonesia. This research is benchmarking to earlier research by Chong and Liu. The parameters being estimated are time deposit interest rate in conventional commercial bank in Indonesia and profit loss sharing rate in mudharabha time deposit in Islamic Commercial bank in Indonesia. Granger Causality Test is used to test if the time deposit interest rate affects the profit loss sharing rate and vice versa. This research shows that the interest rate of time deposit in conventional commercial bank in Indonesia doesn't effect the profit loss sharing rate in mudharabah time deposit in Islamic commercial bank. On the other hand, the profit loss sharing rate in mudharabah time deposit also doesn't effect the interest rate of time deposit in conventional commercial bank in Indonesia.
\end{abstract}

Keywords: Profit Loss Sharing, Interest Rate, Independence, Time of Deposit, Profit Loss Sharing, Granger Causality Test,

Negara yang menganut dual banking sistem selalu diterpa isu independensi bank syariah atas bank konvensional. Penetapan sistem bagi hasil, diduga tidak murni, tetapi masih mengacu kepada tingkat suku bunga bank konvensional. Padahal, secara teoritis terdapat 
perbedaan mendasar antara bank syariah dan bank konsional. Bank syariah menggunakan sistem bagi hasil (profit loss sharing), bank konvensional menggunakan sistem bunga (interest rate). Penelitian ini dilakukan dengan tujuan untuk menguji independensi bank syariah atas bank konvensional. Penelitian ini mengacu kepada penelitian yang telah dilakukan oleh Chong dan Liu (2009). Produk perbankan yang digunakan adalah tingkat suku bunga deposito bank konvensional dan tingkat bagi hasil deposito mudharabah bank syariah di Indonesia. Uji Kausalitas Granger (Granger Causality Test) digunakan untuk menguji apakah tingkat suku bunga deposito bank konvensional mempengaruhi tingkat bagi hasil deposito mudharabah bank syariah, ataukah sebaliknya. Hasil dari penelitian ini menunjukkan bahwa tingkat suku bunga deposito bank konvensional tidak mempengaruhi tingkat bagi hasil deposito mudharabah bank syariah. Demikian juga sebaliknya, tingkat bagi hasil deposito mudharabah bank syariah tidak mempengaruhi tingkat suku bunga deposito bank konvensional.

Kata Kunci: sistem bagi hasil, sistem bunga, independensi, deposito, tingkat suku bunga, tingkat bagi hasil, Uji Kausalitas Granger.

\section{Introduction}

Indonesia is a country that embrace dualbanking system, which adopts the conventional banking and Islamic banking system. There are fundamental differences between these two systems, namely conventional banks use interest rates (interest rate based) Islamic banking and use levels for the results (profit loss sharing).

Raising funds in Islamic banks consist of deposits mudaraba, savings, and checking accounts. Islamic Banking Outlook 2013 noted that the deposits mudaraba is the largest selection of people for the placement of funds in the Islamic Bank, which amounted to Rp 78.9 trillion (58, 39\%). The next largest public fund is a savings. Savings amounting Rp40,84 trillion (30.38\%) and the Giro for Rp15,09 trillion (11.22\%). The distribution of funds is murabaha receivables amounting to $\mathrm{Rp} 80.95$ trillion or $59.71 \%$ followed by Musharaka financing amounting Rp25,21 trillion (18.59\%) and Mudharabah financing amounting Rp11,44 trillion (8.44\%), and receivables Qardh by Rp11,19 trillion (8.25\%). The placement of public funds in Islamic banks, as illustrated in figure 1.1 below: 


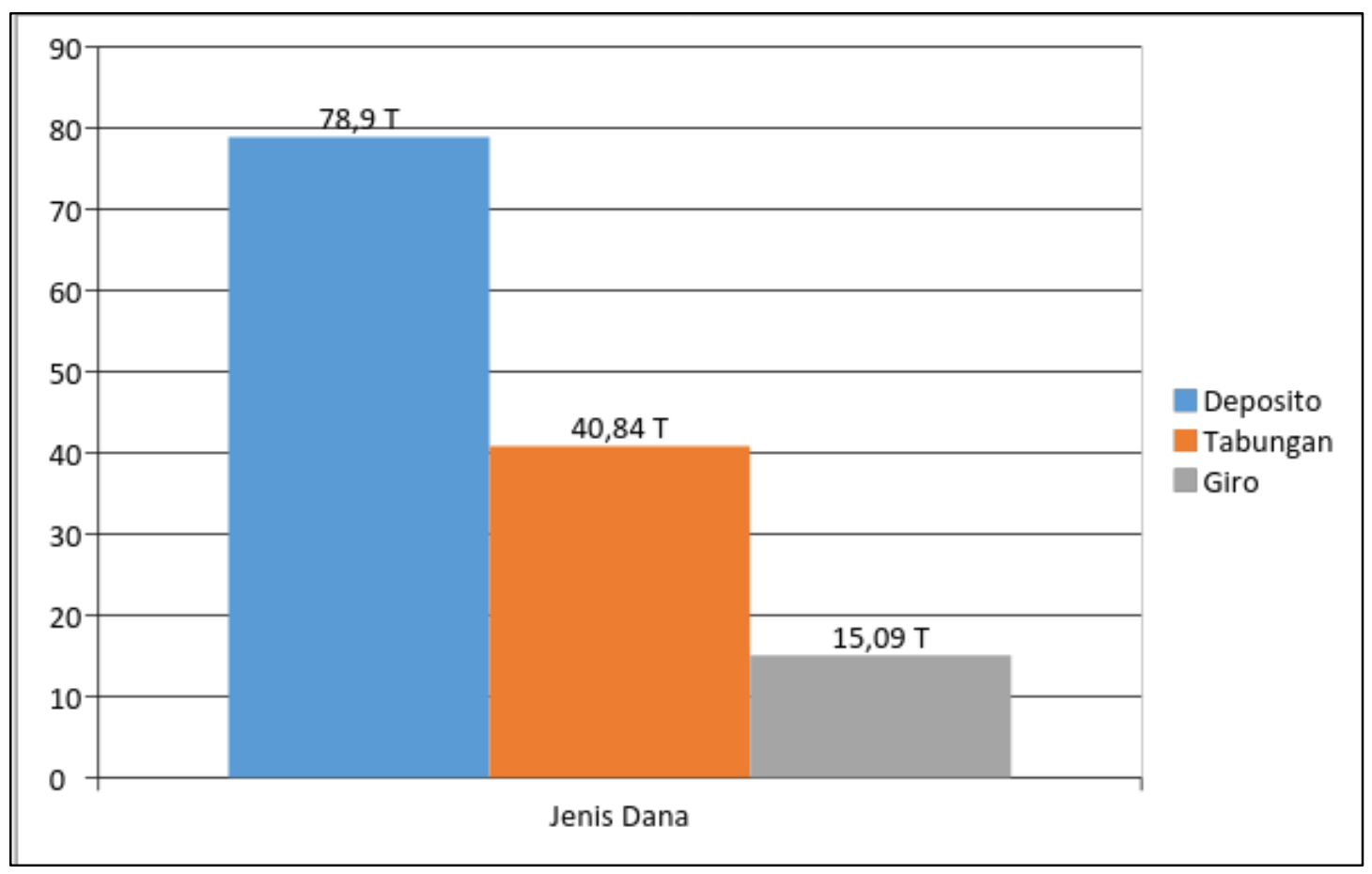

\section{Graph 1. Placement Community Fund at Bank Syariah in 2013}

Source: Data processed

There are several things that attract people to place their funds in the form of deposits mudaraba. Agustianto (2013) on the website of the Association of Islamic Economics (www.iaei-pusat.org) says people interested in placing funds in time deposits mudaraba because the return on deposits is relatively higher than on deposits in conventional banks. Application of revenue sharing system has opened up opportunities investment return greater than the interest system. In addition, the placement of funds in Islamic banks tend to create a sense of safe, secure, quiet and peaceful. Feeling safe, secure, quiet, and peaceful arise not only because of the customer money guaranteed by the government and thus the risk of losing money is small, but also because of the implementation of Islamic system in the bank. Muslim community who care about the rules - the rules listed in the Al - Quran and Hadith would certainly prefer to place their funds in Islamic banks than conventional banks placing funds in embracing system of interest.

Chong and Liu (2009) investigate the application of profit loss sharing in the Malaysian Islamic banks, and possible Islamic banks deposits tied to conventional bank deposits. Liu Chong and research results show that the rapid development of Islamic banks are more influenced by the revival of Islam in the entire world than the awareness of the benefits of profit loss sharing itself. 
Indonesia and Malaysia is a country that adheres to the dual banking system. In addition, the majority of the population of Malaysia and Indonesia are Muslims, so the development of Islamic banks in the two countries is quite rapid. Socio-economic conditions between Indonesia and Malaysia was almost the same. Based on the facts, there is the possibility of Indonesian Islamic banks have the same pattern with Islamic banks in Malaysia.

This study draws on research conducted by Chong and Liu in Malaysia (2009). This study was done to see if the deposit interest rate of conventional bank deposits affect the level of revenue sharing mudaraba Islamic banks or vice versa. To see the pattern of relationship between the level of profit sharing mudaraba deposits of Islamic banks and rate of conventional bank, used Granger Causality Test. The object of research is the level of revenue sharing mudaraba Islamic bank deposits and bank deposit interest rate conventional in Indonesia period January 2010 to October 2013. The study was conducted on Mudharabah deposits of Islamic banks a period of 1 month, 3 months, 6 months, and 12 months as well as deposits conventional banks period with the same period.

Based on the formulation of the problem above, the purpose of this study as follows: First, empirical test whether the level of interest rates affect the level of conventional bank deposits for the deposits mudaraba Islamic banks. Second, empirical test whether the level of profit sharing mudaraba deposits affect the interest rate on bank deposits of conventional.

\section{Literature review}

Deposit

Deposit is one of the products that are used by banks to raise third party funds (funds from the public). Deposit is one of the most potential collect of public funds in the banking world. Such potential deposits that Barney Kilgore, - a director of Dow Jones \& Company and publisher of The Wall Street Journal - once said (Rose \& Hudgins, 2013):

"Do not write banking stories for bankers. Write for the bank's customers. There are a lot more hell depositors than bankers'

Barney statement implicitly shows how important the role of deposit in the banking world.

According Latumerissa (2012), deposits included in the group of funds expensive for interest to be paid by the bank to the depositor is relatively high when compared with the product - other savings products such as checking accounts and savings accounts. Nevertheless, the most loved bank deposits since the mobility of small relative deposits, so banks are more easily estimate its liquidity needs. Depositors will not withdraw deposits before maturity, so that deposits can be used by the bank to earn revenue. 
There are several types of deposits. According Kuncoro and Suhardjono (2011), the deposit is divided into:

1. Demand deposits (demand deposits)

Giro is a third party deposits at banks that withdrawal can be made at any time by check, other payment warrant, or by overbooking. The target market is the demand deposits of all levels of society, both individuals and business entities in the profession needs help banks to complete the payment transaction.

2. Deposits (time deposits)

Deposits are time deposits issued by banks which may only be withdrawn within a certain period in accordance with the time promised. There are two types of deposits, ie time deposits and certificates of deposit. The difference of these two types of deposits can be seen in Table 1 below:

Table 1. Differences Deposits and Certificates of Deposit

\begin{tabular}{|c|l|l|l|}
\hline & \multicolumn{1}{|c|}{ Differences } & \multicolumn{1}{|c|}{ Deposits } & Certificates of Deposit \\
\hline 1 & Payment of interest & $\begin{array}{l}\text { Each due date interest / } \\
\text { principal }\end{array}$ & $\begin{array}{l}\text { When opening an account } \\
\text { (discounted) }\end{array}$ \\
\hline 2 & Assignment & Can not be transferred & To be transferred \\
\hline 3 & Ownership & On behalf of & Upper rally \\
\hline 4 & $\begin{array}{l}\text { Calculation of } \\
\text { interest }\end{array}$ & Not discounted & Discounted \\
\hline
\end{tabular}

Source: Kuncoro dan Suhardjono, 2011

Payment of interest on deposits are each due date interest / principal, while certificates of deposit, interest is payable at the opening of the account. Time deposits are not transferable, while certificates of deposit can be transferred. This leads to the ability to transferable ownership certificates of deposit are bearer. This means that anyone who holds a certificate of deposit can withdraw the funds that recorded in the certificate of deposit. It instead for deposits. Owners deposits are in the name. This means that only the person whose name appears on the letter of deposit are eligible to withdraw funds such deposits. Calculation of interest on time deposits are not discounted, while certificates of deposit discounted. The target market for deposits is all layers of society, both individuals and business entities. 


\section{Interest Rate}

Rewards to customers who put their money in conventional banks, is of interest. There are several definitions related to interest. According to Hubbard (2007), the interest is a cost to be paid by the borrower (debitor) for funds received and reward those who lend (creditors) on the investment made. Mishkin (2007) says that the interest rate is the cost or the price paid for the rental funds - funds. Mishkin looked at the interest rate of the borrower (borrower). Pindyck and Rubinfeld (2005) also argue that the interest rate is the price paid by the borrower to the lender. Such as market prices, the determination of the interest rate is determined by demand and supply of Loanable funds.

Siamat (2005) distinguishes the notion of interest in two perspectives, namely:

1. Interest of the demand side. Flowers from the demand side to the income of the credit crunch. Interest is a lease or price of money.

2. Interest on the supply side. Own funds are going to use or allocate funds on the type of investments that promise higher interest payments.

There are two kinds of flowers provided by conventional banks to customers:

a. Deposit rates.

Deposit interest is the purchase price to be paid to the customer holding bank deposits. Interest given as a stimulus or as a reward to customers who invest in the bank. For example, interest on savings, interest on deposits, and current accounts.

b. Loan interest

The loan interest is the interest charged to the borrower (debitor) or the selling price to be paid by the borrower to the bank's customers. For bank, lending interest is a selling price. Eg mortgage interest.

The size of interest rates on deposits and loans is strongly influenced by both the component itself. That is, both the interest rate savings and loan mutual influence, in addition to the factors - other factors also have an effect on the determination of interest rates.

Costs incurred for deposit products, should be smaller than the revenue earned from the distribution of funds that banks make a profit. This is what underlies the application of the borrowing rate is greater than the interest rates on deposits. Interest rates on deposits coupled with a variety of elements used as a basis to determine the level of interest rates on loans 


\section{Islamic Bank}

In general, Islamic bank is a bank operating under Islamic principles, namely referring to $\mathrm{Al}$ - Quran and Hadith. The definition implies that the activities of Islamic banks are required to avoid practices which contains elements of usury and conduct their business activities on the basis of the terms of investment and trade financing.

Antonio and Perwataatmadja (1997) in Muhammad (2004) distinguish the definition of the notion of Islamic Bank into two, namely:

1. Bank which operates on the principle of Islamic law, meaning that the bank in conducting business activities comply with the provisions of Islamic law, especially regarding the procedures muamalat in Islam. Muamalat Islamic ordinances are executed in a way away from practice - a practice that is feared contain elements - elements of usury. Investments made under profit-sharing and trade financing.

2. The Bank is planning searching operation of the provisions referred to Al - Quran and Hadith.

Thus, there is a fundamental difference between conventional banks and Islamic banks. Antonio (2007) describes these differences as presented in Table 2 below :

Table 2. Differences in Islamic Banking and Conventional

\begin{tabular}{|c|c|c|}
\hline No & Syariah Bank & Convensional Bank \\
\hline 1. & Invest in a lawful under Islamic law. & $\begin{array}{l}\text { Make investments both licit and illicit under } \\
\text { Islamic law }\end{array}$ \\
\hline 2. & $\begin{array}{l}\text { Using the principle of sharing, purchase, } \\
\text { or lease }\end{array}$ & The device using interest rates \\
\hline 3. & $\begin{array}{l}\text { Profit-oriented and Falah (happiness of } \\
\text { the world and the hereafter according to } \\
\text { the Islamic) }\end{array}$ & Oriented profits \\
\hline 4. & $\begin{array}{l}\text { Relationships with customers in the form } \\
\text { of partnership }\end{array}$ & $\begin{array}{l}\text { Relations with customers in the form of } \\
\text { creditor - debitor }\end{array}$ \\
\hline 5. & $\begin{array}{l}\text { The collection and distribution of funds in } \\
\text { accordance with the fatwa Sharia }\end{array}$ & $\begin{array}{l}\text { Supervisory Board of Collection and } \\
\text { distribution of funds not governed by a } \\
\text { board similar Sharia Supervisory Board }\end{array}$ \\
\hline
\end{tabular}

Source: Antonio (2007) 
Based on Table 2, it seems all the activities of Islamic banks back to the basic rules that apply in Al - Quran and Hadith. Islamic banks are not allowed to invest into the business that is not kosher or halal doubt. The principle used when making investment or raise funds is the principle of sharing, purchase, or lease.

\section{Level Sharing}

Allah says in Al - Quran surah An - Nisa verse 29. The meaning of the letter as follows: "Peole who believe, do not eat each other neighbor's property by way of vanity, except by way of commerce that goes with the same love between you. And do not kill yourselves verily Allah is Merciful to you"

In Surat an - Nisa verse 29 it is said that it is forbidden for a Muslim to eat each other treasures fellow with the vanity. "The vanity" is interpreted by experts as a treasure usury.

Riba in the sense of meaningful additional languages (ziyadah). Linguistic meaning of usury is to grow and expand. Meaning of usury is technically the additional load of treasure principal / capital vanity (Antonio M. S., 2007). A Muslim is not allowed to conduct commercial transactions muamalah or that contain elements of usury. Every transaction made, always based on the elements of the exchange of goods with money, and no forced elements of both parties (seller and buyer).

The principle stated in Surah An - Nissaa: 29 is also valid for Islamic banks. As one of the Islamic financial institutions, Islamic banks benefit from a share of the funds invested to customers. For these results which will be distributed to savers.

There are two models of calculation of benefits in Islamic banks, namely:

1). Profit sharing, the calculation for results based on the net result of total revenues after deducting costs incurred to earn that income.

2). Revenue sharing, the calculation for results based on the total of all income received before deducting costs incurred to earn that income.

Islamic banks can use one of these two systems, depending on the policy of each bank. If the bank uses a system of profit sharing, then the profits earned by shahibul maal (owner of the funds) is relatively small when compared with the use of revenue sharing system. Policy decisions on the use of the revenue sharing system have a significant impact if the market interest rate is higher than the level for acceptable results customers. When this 
condition occurs, then the people's desire to invest in Islamic banks will decline, so that third party funds will also decrease.

If Islamic banks want to establish a system of profit sharing, the bank must set aside part of the proceeds received bank, to subsidize the results received by the customer (depositor). This means that the portion of the bank's profit will be reduced to cover the shortfall for the proceeds to be received by depositors.

In contrast, if banks use revenue sharing methods, it is possible for the result obtained by the customer is higher when compared with conventional bank interest rate. As a result, customers will be interested to place their funds in Islamic banks. The increase in the number of customers is certainly increasing third party funds. Improved terms of this funding should ideally be followed by an increase in financing. This means that banks need to channel these funds into businesses - businesses that are productive, decent and capable of increasing the maximum profitability for the owner of the funds.

Determination method for this result to be determined at the beginning of the cooperation contract, in the form of share of profits each party. Example: determination of the result 40:60, meaning profits will be divided $40 \%$ to the owner of the funds (shahibul maal) and $60 \%$ for the fund manager (mudharib). Sharing ratio determined in the shape of a percentage, for example 30:70, 40:60, 50:50 or even 1:99. The amount of the profit sharing ratio determined together - equally by both parties.

\section{Hypothesis Development}

Arif (2010) conducted a study on the effect of interest rate conventional banks as one of the factors in determining the margin of profit sharing in Islamic banks. The analysis tool used is regression distribution lag. The results obtained from this study is the conventional bank interest rate has a significant influence in determining the margin of profit sharing in Islamic banks. Based on this, Arif concluded that the determination of the margin of profit sharing in Islamic banks can not be separated from the determination of the conventional bank rate. In other words, the conventional bank interest rates become a reference role in determination of margins for the results in Islamic banks.

Chong and Liu (2009) conducted a study using the variable interest rate on deposits of $1,3,6$, and 12 months of commercial banks and finance companies in Malaysia as well as the level of revenue sharing mudaraba deposits of Islamic banks and Islamic financial company in Malaysia. The analysis tool used is the Granger Causality Test. Granger causality 
test is used to look at the direction of causality between a variable rate for the deposits mudaraba Islamic bank with conventional bank interest rate. Based on research Chong and Liu (2009), developed the hypothesis of this study as follows:

1. Ha1 = suspected of bank deposit interest rate conventional 1-month period significantly affect the level of revenue sharing mudaraba Islamic bank deposits 1-month period.

2. Ha2 = suspected level of revenue sharing mudaraba Islamic bank deposits 1-month period significantly affect the interest rate on bank deposits of conventional 1-month period.

3. Ha3 = suspected of bank deposit interest rate conventional 3-month period significantly affect the level of revenue sharing mudaraba Islamic bank deposits 3-month period.

4. Ha4 = suspected level of revenue sharing mudaraba Islamic bank deposits 3-month period significantly affect the interest rate on bank deposits of conventional 3-month period.

5. Ha5 = suspected of bank deposit interest rate conventional 6-month period significantly affect the level of revenue sharing mudaraba Islamic bank deposits 6-month period.

6. Ha6 = suspected level of revenue sharing mudaraba Islamic bank deposits 6-month period significantly affect the interest rate on bank deposits of conventional 6 month period.

7. Ha7 = suspected of bank deposit interest rate of conventional 12-month period significantly affect the level of revenue sharing mudaraba deposits of Islamic banks 12-month period.

8. Ha8 = suspected level of revenue sharing mudaraba deposits of Islamic banks 12-month period significantly affect the interest rate on bank deposits of conventional 12 month period. 


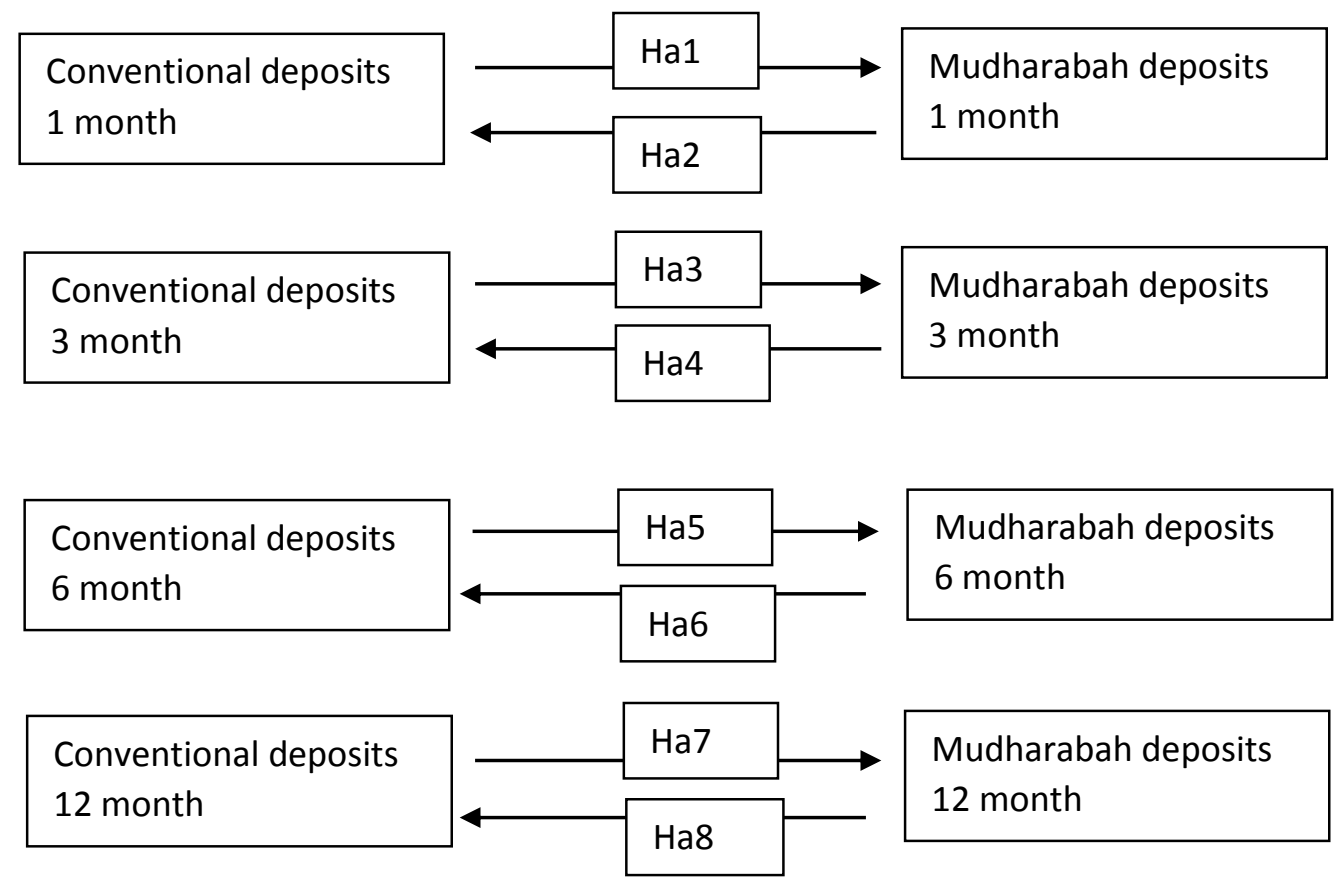

Figure 2. Research Model

\section{Methodology}

\section{Research design}

This study was a descriptive - causal. Descriptive research is research that contains information presented in graphs, tables, and contain exposure - exposure of the data - the data obtained (Anderson, Sweeney, Williams, Camm, \& Cochran, 2013). Causal research is research that shows the direction of the relationship between independent variables and the dependent variable, and measuring the strength of the relationship.

\section{Operational Definition of Variables}

This study is a study that examines the determination of whether the interest rate on bank deposits of conventional affect the level of profit sharing mudaraba Islamic bank deposits, or deposits Mudharabah profit sharing rate affects the interest rates of conventional deposits. Therefore it can not be determined variables that act as independent variables and the dependent variable. Determination of free and bound variables can be done after a Granger causality test. Below is a table of measurement variables involved in this study. 
Table 3. Variable Operational Definition and Measurement Scale

\begin{tabular}{|c|c|c|c|}
\hline No & Variable & $\begin{array}{l}\text { Indicators and } \\
\text { Measurement }\end{array}$ & Measure scale \\
\hline 1. & $\begin{array}{l}\text { The interest rate on } \\
\text { conventional deposits } \\
1 \text { month }\end{array}$ & $\begin{array}{l}\text { The value to be paid to the } \\
\text { customer holding bank } \\
\text { deposits 1-month period }\end{array}$ & Ratio \\
\hline 2. & $\begin{array}{l}\text { The interest rate on } \\
\text { conventional deposits } \\
3 \text { month }\end{array}$ & $\begin{array}{l}\text { The value to be paid to the } \\
\text { customer holding bank } \\
\text { deposits 3-month period }\end{array}$ & Ratio \\
\hline 3. & $\begin{array}{l}\text { The interest rate on } \\
\text { conventional deposits } \\
6 \text { month }\end{array}$ & $\begin{array}{l}\text { The value to be paid to the } \\
\text { customer holding bank } \\
\text { deposits } 6 \text {-month period }\end{array}$ & Ratio \\
\hline 4. & $\begin{array}{l}\text { The interest rate on } \\
\text { conventional deposits } \\
12 \text { month }\end{array}$ & $\begin{array}{l}\text { The value to be paid to the } \\
\text { customer holding bank } \\
\text { deposits 12-month period }\end{array}$ & Ratio \\
\hline 5. & $\begin{array}{l}\text { Level for the deposits } \\
\text { mudharabah } 1 \text { month }\end{array}$ & $\begin{array}{l}\text { Profits to be paid by the bank } \\
\text { to customers mudharabah } \\
\text { deposits with a period of } 1 \\
\text { month. }\end{array}$ & Ratio \\
\hline 6. & $\begin{array}{l}\text { Level for the deposits } \\
\text { mudharabah } 3 \text { month }\end{array}$ & $\begin{array}{l}\text { Profits to be paid by the bank } \\
\text { to customers mudharabah } \\
\text { deposits with a period of } 3 \\
\text { month. }\end{array}$ & Ratio \\
\hline 7. & $\begin{array}{l}\text { Level for the deposits } \\
\text { mudharabah } 6 \text { month }\end{array}$ & $\begin{array}{l}\text { Profits to be paid by the bank } \\
\text { to customers mudharabah } \\
\text { deposits with a period of } 6 \\
\text { month. }\end{array}$ & Ratio \\
\hline 8. & $\begin{array}{l}\text { Level for the deposits } \\
\text { mudharabah } 12 \text { month }\end{array}$ & $\begin{array}{l}\text { Profits to be paid by the bank } \\
\text { to customers mudharabah } \\
\text { deposits with a period of } 12 \\
\text { month. }\end{array}$ & Ratio \\
\hline
\end{tabular}

\section{Test Descriptive Statistics}

The study used the descriptive statistics seen from the average - average (mean), standard deviation (standard deviation), and maximum value - the minimum a variable studied. Mean used to estimate the average large - estimated population average of the 
sample. Standard deviation is used to assess dispersions - average of the sample. Maximum - Minimum used to see the maximum and minimum values of the population.

\section{Stasionaritas Test Data}

Before performing the Granger causality test, first tested the stasionaritas data. Stasionaritas test data or often called the unit root test (unit root test) is a test that is performed to see if a certain coefficient of dynamic models were estimated to have a value of one or equal to one (Aliman, 2000, p. 112). Stasionaristas test data is done using Augmented Dickey - Fuller Test (ADF Test).

\section{Granger Causality Test}

Causality test is performed to determine whether an endogenous variable can be treated as an exogenous variable. Gujarati (2003, p. 696) provides an example for a variable Gross Domestic Product (GDP) does have a causal relationship with the variable Money Supply (M). to test two of these variables, the model estimate is as follows:

$$
\begin{gathered}
G D P_{t}=\sum_{i=1}^{n} \alpha_{i} M_{t-1}+\sum_{j=1}^{n} \beta_{j} G D P_{t-j}+\mu_{1 t} \\
M_{t}=\sum_{i=1}^{n} \lambda_{i} M_{t-1}+\sum_{j=1}^{n} \beta_{j} G D P_{t-j}+\mu_{2 t}
\end{gathered}
$$

Information:

$\mu 1 \mathrm{t}$ and $\mu 2 t$ is confounding variables and both are assumed to be uncorrelated. Furthermore, with the dependent variable GDP equation called the equation 1, while the dependent variable equation called the equation M 2.

Null hypothesis is $\mathrm{Ho}: \sum_{i=1}^{n} \alpha_{i}=0$

Based on these similarities, there are four outcomes that can occur:

1. Unidirectional causality from $M$ to GDP.

Unidirectional condition of causality from M to GDP lag occurs when the estimated coefficient $\mathrm{M}$ in equation 1 are statistically equal to 0 , and the coefficient estimate to lag GDP in equation 2 is equal to 0. 
2. Unidirectional causality from GDP to $M$.

Unidirectional condition of causality from GDP to M occurs when the estimated coefficient lag $M$ in equation 1 is statistically equal to 0 , and the coefficient estimate to lag GDP in equation 2 is not equal to 0 .

3. Feedback, or bilateral causality, occurring when M and GDP coefficients are statistically equal to 0 for equations 1 and 2 .

4. Independence, mutually independent conditions occur when both coefficients are statistically equal to 0 .

\section{Result and Discussion}

Descriptive statistics

Table 4. Descriptive Statistics

\begin{tabular}{|l|l|l|l|l|l|}
\hline & N & Minimum & Maximum & Mean & $\begin{array}{c}\text { Std. } \\
\text { Deviation }\end{array}$ \\
\hline DM1 & 46 & 0.033400 & 0.077400 & 0.061798 & 0.008759 \\
\hline DM3 & 46 & 0.047700 & 0.092500 & 0.065098 & 0.010079 \\
\hline DM6 & 46 & 0.044300 & 0.089500 & 0.066811 & 0.007587 \\
\hline DM12 & 46 & 0.052400 & 0.086400 & 0.067254 & 0.007217 \\
\hline KONV1 & 46 & 0.054300 & 0.069900 & 0.061209 & 0.005577 \\
\hline KONV3 & 46 & 0.057100 & 0.072100 & 0.065391 & 0.005277 \\
\hline KONV6 & 46 & 0.059000 & 0.072700 & 0.066646 & 0.004675 \\
\hline KONV12 & 46 & 0.057700 & 0.078400 & 0.067328 & 0.005751 \\
\hline
\end{tabular}

Source: Data processed

In Table 4 above, it is known:

1. Variable DM1 (level of revenue sharing mudaraba Islamic bank deposits 1-month period) has a minimum value of 0.033400 , with a maximum value of 0.077400 , the average average DM1 of 46 observation standard deviation of 0.061798 to 0.008759 .

2. Variable DM3 (level of revenue sharing mudaraba Islamic bank deposits 3-month period) has a minimum value of 0.047700 , with a maximum value of 0.092500 , the average average DM3 from 46 observation standard deviation of 0.065098 to 0.010079 .

3. Variable DM6 (level of revenue sharing mudaraba Islamic bank deposits 6-month period) has a minimum value of 0.0443000 , with a maximum value of 0.089500 , the average average DM6 of 46 observation standard deviation of 0.066811 to 0.007587 . 
4. Variable DM12 (level of revenue sharing mudaraba Islamic bank deposit period of 12 months) has a minimum value of 0.052400 , with a maximum value of 0.086400 , the average - average DM12 of 46 observations with standard deviation of 0.067254 0.007217.

5. Variable KONV1 (conventional bank interest rate period of 1 month) has a minimum value of 0.054300 , with a maximum value of 0.069900 , the average - average KONV1 of 46 observation standard deviation of 0.061209 to 0.005577 .

6. Variable KONV3 (conventional bank interest rate period of 3 months) has a minimum value of 0.057100 , with a maximum value of 0.072100 , the average - average KONV3 of 46 observation standard deviation of 0.065391 to 0.005277 .

7. Variable KONV6 (conventional bank interest rate period of 6 months) has a minimum value of 0.059000 , with a maximum value of 0.072700 , the average - average KONV6 of 46 observation standard deviation of 0.066646 to 0.004675 .

8. Variable KONV12 (conventional bank interest rate period of 12 months) has a minimum value of 0.057700 , with a maximum value of 0.078400 , the average - average KONV12 of 46 observation standard deviation of 0.067328 to 0.005751 .

\section{Stasionaritas Test Result Data}

This study was preceded by stasionaritas test data. Eighth variable has been done stasionaritas test data and results are summarized in Table 5 Test stasionaritas this data using Augmented Dickef Fuller Test. Software used is Eviews 6. Variables that are stationary at levels other than the level of the variable name change and for the next steps, variables used are variables that are stationary.

Table 5. Stasionaritas Test Result Data

\begin{tabular}{|c|l|l|l|l|l|}
\hline No & Variable & ADF Stat & $\begin{array}{c}\text { Critical } \\
\text { Value 5\% }\end{array}$ & Conclusion & $\begin{array}{l}\text { Variable } \\
\text { Changes }\end{array}$ \\
\hline 1. & DM1 & -7.494544 & -2.929734 & Stationary at 1st difference & DDM1 \\
\hline 2. & DM3 & -6.127197 & -2.929734 & Stationary at 1st difference & DDM3 \\
\hline 3. & DM6 & -7.895197 & -2.931404 & Stationary at 1st difference & DDM6 \\
\hline 4. & DM12 & -8.454766 & -2.935001 & Stationary at 1st difference & DDM12 \\
\hline 5. & KONV1 & -3.964784 & -2.929734 & Stationary at 1st difference & DKONV1 \\
\hline
\end{tabular}




\begin{tabular}{|c|l|l|c|l|c|}
\hline No & Variable & ADF Stat & $\begin{array}{c}\text { Critical } \\
\text { Value 5\% }\end{array}$ & \multicolumn{1}{|c|}{ Conclusion } & $\begin{array}{c}\text { Variable } \\
\text { Changes }\end{array}$ \\
\hline 6. & KONV3 & -7.196962 & -2.931404 & $\begin{array}{l}\text { Stationary on 2nd } \\
\text { difference }\end{array}$ & D2KONV3 \\
\hline 7. & KONV6 & -9.124217 & -2.931404 & $\begin{array}{l}\text { Stationary on 2nd } \\
\text { difference }\end{array}$ & D2KONV6 \\
\hline 8. & KONV12 & -4.005426 & 2.945842 & Stationary at level & KONV12 \\
\hline
\end{tabular}

Source: Data processed

Most of the studied variables are not stationary at the current level. Only conventional deposits 12-month period (KONV12) are stationary at the level. Variable Deposit Mudharabah period of 1 month (DM1), the Deposit Mudharabah 3-month period (DM3), Deposit Mudharabah period of 6 months (DM6), Deposit Mudharabah 12 months (DM12), and deposits Conventional 1-month period (KONV1) stationary in 1st difference. Conventional deposits of 3 months and 6 months (KONV3 and KONV6) stationary in 2nd difference.

\section{Granger Causality Test}

After testing stasionaritas data, the next step is to Granger Causality Test. Granger Causality Test is performed on the second lag. Here is a summary of the Granger Causality Test against eight variables studied.

Table 6. Granger Causality Test Results

\begin{tabular}{|r|c|c|c|}
\hline No & Ho & F- statistic & $p$-value \\
\hline $\mathbf{1 .}$ & DKONV1 does not Granger Cause DDM1 & 0.28735 & $0.7519^{*}$ \\
\hline $\mathbf{2 .}$ & DDM1 does not Granger Cause DKONV1 & 0.22555 & $0.7991^{*}$ \\
\hline $\mathbf{3 .}$ & D2KONV3 does not Granger Cause DDM3 & 1.21556 & $0.3081^{*}$ \\
\hline $\mathbf{4 .}$ & DDM3 does not Granger Cause D2KONV3 & 1.09599 & $0.3448^{*}$ \\
\hline $\mathbf{5 .}$ & D2KONV6 does not Granger Cause DDM6 & 1.08238 & $0.3493^{*}$ \\
\hline $\mathbf{6 .}$ & DDM6 does not Granger Cause D2KONV6 & 3.17296 & $0.0535^{\star}$ \\
\hline $\mathbf{7 .}$ & KONV12 does not Granger Cause DDM12 & 1.11192 & $0.3394^{\star}$ \\
\hline $\mathbf{8 .}$ & DDM12 does not Granger Cause KONV12 & 2.23277 & $0.1211^{*}$ \\
\hline
\end{tabular}

${ }^{*}$ level of significance $=5 \%$, 
Based on table 6, it is known that none of the null hypothesis proposed in this study was rejected. Eighth Ho everything can not be denied. That is, the variable mudaraba deposits and conventional deposits variables do not have a causal relationship. Here's a brief description of each hypothesis:

\section{Ha1: Suspected rate of conventional bank deposits 1-month period significantly} affect the level of revenue sharing mudaraba Islamic bank deposits 1-month period.

Statement for Ha1 is represented by the number 1 in table 4.3. Test this hypothesis using the approach $p$ - value, so this would be the value of $p$ - value. Value $p$ value is then compared with the level of significance $(\alpha)$ of $5 \%$. Based on Granger causality test, it is known that the value of $p$ - value for the statement "DKONV1 not a Granger causality to DDM1" is 0.7519 . Thus the value of $p$ - value for Ha1 is greater than the level of significance (5\%), so Ho could not be denied. Meaning: the interest rate on bank deposits of conventional 1-month period does not affect the level of profit sharing mudaraba Islamic bank deposits 1-month period.

Ha2: Suspected level of revenue sharing mudaraba Islamic bank deposits 1-month period significantly affect the interest rate on bank deposits of conventional 1-month period.

Ha2 statement is represented by the number 2 in table 4.3. The p-value - value for the statement "DDM1 not a Granger causality to DKONV1" amounted to 0.7991. When compared primarily to the level of significance of $5 \%$, the value of $p$ - value is greater than the value $\alpha$, so that Ho could not be denied. Meaning: level of revenue sharing mudaraba Islamic bank deposits 1-month period does not affect the deposit interest rate conventional 1-month period.

HA3: Suspected bank deposit interest rate conventional 3-month period significantly affect the level of revenue sharing mudaraba Islamic bank deposits 3-month period.

HA3 statement is represented by the results of Granger causality test number 3. The $p$ - value for the test of the value of 0,3081 , was greater than the value of $\alpha$. Ho thus can not be rejected. This means that the variable interest rate on bank deposits of conventional 3-month period does not affect the level of profit sharing mudaraba Islamic bank deposits 3-month period. 
Ha4: Suspected rate for the deposits mudaraba Islamic bank 3-month period significantly affect the interest rate on bank deposits of conventional 3month period.

Hypothesis to 4 is represented by the number 4 in table 4.3. Ho from hypothesis to 4 this is the level of revenue sharing mudaraba Islamic bank deposits 3-month period did not significantly affect the interest rate on bank deposits of conventional 3-month period. The $p$-value - the value of Granger causality test this hypothesis to 4 at 0.3448 which is also greater in value when compared with the level of significance (5\%). Ho thus can not be rejected. This means that the variable rate for the deposits mudaraba Islamic bank 3-month period did not significantly affect the interest rate on bank deposits of conventional 3-month period.

HA5: Suspected bank deposit interest rate conventional 6-month period significantly affect the level of revenue sharing mudaraba Islamic bank deposits 6-month period.

Hypotheses to 5 is represented by the number 5 in table 4.3 (D2KONV6 does not Granger Cause DDM6). The $p$-value of the test to this 5 at 0.3493 . When compared with the value of $\alpha$, the value of $p$ - value is greater. It can be concluded that the interest rate on bank deposits of conventional 6-month period does not affect the level of profit sharing mudaraba Islamic bank deposits 6-month period.

Ha6: Suspected level of revenue sharing mudaraba Islamic bank deposits 6-month period significantly affect the interest rate on bank deposits of conventional 6-month period.

Hypothesis to 6 is represented by the results of Granger causality test number 6 in Table 4.3. Value $p$ - value hypothesis to 6 is 0,0535 level of significance $5 \%$, then Ho can not be denied. That is, the level of revenue sharing mudaraba Islamic bank deposits 6-month period does not affect the interest rate on bank deposits of conventional 6-month period. Thus, the level of revenue sharing mudaraba Islamic bank deposits 6-month period to not affect the interest rate on bank deposits of conventional 6-month period.

Ha7: Suspected bank deposit interest rate of conventional 12-month period significantly affect the level of revenue sharing mudaraba deposits of Islamic banks 12-month period.

Hypothesis to seven are represented by the number 7 in Table 4.3. Value $p$ - value hypothesis to 7 is 0.3994 . Thus the value of $p$ - value is greater than the value level 
of significance of $5 \%$, so that Ho could not be denied. That is, the interest rate on bank deposits of conventional 12-month period did not significantly affect the level of profit sharing mudaraba deposits of Islamic banks 12-month period.

\section{Ha8: Suspected rate for the deposits mudaraba Islamic banks 12-month period significantly affect the interest rate on bank deposits of conventional 12- month period.}

Hypotheses to eight represented by the number 8 in Table 4.3. Value $p$ - value hypothesis to eight is 0.1211 . Thus the value of $p$ - value is greater than $\alpha(5 \%)$, so Ho could not be denied. That is, the level of revenue sharing mudaraba deposits of Islamic banks 12-month period does not affect the interest rate on bank deposits of conventional 12-month period.

The results of the calculations in Granger Causality Test shows that the relationship between the variable interest rate on deposits in conventional banks and the level of revenue sharing mudaraba deposits in Islamic banks are mutually independent. This means that there is no connection or interplay between deposits mudaraba Islamic bank with an interest rate of conventional bank deposits.

\section{Managerial Implication}

Managerial implication made by Islamic banks are based on some of the following is the result of the previous discussion:

1. Variable rate for the deposits of Islamic banks 1-month period (DM1) have a relationship independent of the variable interest rate of conventional bank deposits 1-month period (KONV1). This means that the two variables are not mutually influence one another

2. Variable rate for the deposits of Islamic banks 3-month period (DM3) have a relationship independent of the variable interest rates on bank deposits of conventional 3-month period (KONV3). This means that the two variables are not mutually influence each other.

3. Variable rate for the deposits of Islamic banks 6-month period (DM6) have a relationship independent of the variable interest rates on bank deposits of conventional 6 -month period (KONV6).

4. Variable rate for the deposits of Islamic banks 12-month period (DM12) have a relationship independent of the variable interest rates on bank deposits of conventional 12-month period (KONV12). This means that the two variables are not mutually influence each other. 
Based on the four-point summary, it can be said that there is no relationship of mutual influence (independent) between conventional deposits period of 1 month, 3 months, 6 months, and 12 months with a rate for the deposits mudaraba Islamic banks in the same period.

The results of this study different from the results of research conducted by Chong and Liu (2009). Liu Chong research and reinforces the notion that the rate for the deposits of Islamic banks is affected by interest rates of conventional bank deposits, whereas this study actually rejecting the notion that the rate for the deposits of Islamic banks is affected by the interest rate on deposits of conventional banks.

There are various things that cause differences between this study with research conducted by Chong and Liu.

1. Place the study.

Research conducted by Chong and Liu conducted in the country of Malaysia. Negara Malaysia is the first country to apply the Islamic banking system than the country of Indonesia. Thus, alleged that Malaysia is more stable in implementing Islamic banking system.

2. The period of the study.

Liu Chong and conduct research in Malaysia with the time period April 1995 - April 2004 (10 years old). The time period of this study was January 2010 - October 2013. When compared with the research and Liu Chong, the period of time taken by the researchers is relatively short, so it is possible to appear a different result. Although Islamic banking has been applied since 1992 in Indonesia, but the model of reporting at Bank Indonesia is not raw, often change - change, until finally in January 2010 began reporting model obtained uniform from year to year.

3. The object of research.

The object of Liu Chong research is the banking and financial institutions both conventional and Islamic, whereas this research is only limited to the banking only. Intake of different research objects can also cause the results are different too.

Based on the analysis of data as described in the previous chapter, then policy makers related to Islamic banking there are some things that can be used as input, include:

1. The interest rate on conventional bank deposits proved not to have an influence on the level of profit sharing mudaraba deposits of Islamic banks. Thus, the variable interest rate 
is not a significant factor as the basis for consideration in decision making related to the profit sharing rate of Islamic banks.

2. The interest rate is not a factor influencing factor to encourage the performance of Islamic banking. Customers suspected Islamic banks have other considerations besides interest rates while deciding to keep their funds in Islamic banks.

\section{Conclusion}

This study aims to determine the relationship of causality between the level of revenue sharing mudaraba Islamic bank deposits with an interest rate of conventional bank deposits. Based on the analysis and discussion that has been described on the causality variable rate for the deposits mudaraba Islamic bank with an interest rate of conventional bank deposits, it can be concluded that the interest rate on conventional bank deposits do not affect the level of profit sharing mudaraba deposits of Islamic banks. Secondly, the rate for the deposits mudaraba Islamic banks do not affect the level of interest rates on conventional bank deposits. Thus, there is no interplay between the interest rate on bank deposits with the conventional level of revenue sharing mudaraba deposits of Islamic banks.

The results of this study support the theory that between conventional banks and Islamic banks no interplay. Conventional banks have different principles with Islamic banks, making it less likely that the decision on interest rates on bank deposits of conventional influenced by the level of profit sharing mudaraba Islamic bank deposits, or vice versa.

A comparison of Islamic banks and conventional banks in Indonesia is an interesting research to be done. Several few things related to the researchers suggest further research. Future studies can expand the scope of the study not only interms of funding but also in terms of lending activities. The object of research is not limited to banking institutions, but other financial institutions can also be analysed with other alternative methods.

\section{References}

Agustianto. (2013, September 25). www.iaei-pusat.org. Retrieved September 10, 2014, from http://www.iaei-pusat.org/article/perbankan/-deposito-syariah-karakteristik-dan-dayatariknya-?language=id

Aliman. (2000). Modul Ekonomika Terapan. Yogyakarta: PAU Studi Ekonomi.

Anderson, D. R., Sweeney, D. J., Williams, T. A., Camm, J. D., \& Cochran, J. J. (2013). Statistics for Business \& Economics (12 ed.). Boston: Cengage Learning. 
Antonio, M. S. (2007). Bank Syariah: Dari Teori ke Praktek (11 ed.). Jakarta: Gema Insani Pers.

Antonio, M. S., \& Perwataatmadja, K. (1997). Apa dan Bagaimana Bank Islam. Yogyakarta: PT. Dana Bhakta Wakaf.

Arif, M. N. (2010). Tingkat Suku Bunga Bank Konvensional dan Pengaruhnya terhadap Penetapan Tingkat Bagi Hasil di Bank Syariah. Jurnal Dialog Balitbang Kemenag RI, 33, 80 - 93.

Chong, B. S., \& Liu, M.-H. (2009). Islamic Banking: Interest Free or Interest Based. Pacific Basin Finance Journal, 125.

Gujarati, D. N. (2003). Basic Econometrics (4 ed.). Singapore: McGraw - Hill Higher Education.

Haron, S., \& Ahmad, N. (2000). The Effects of Conventional Interest Rate and Rate of Profit on Funds Deposited wish Islamic Banking System in Malaysia. International Journal of Islamic and Financial Services, 1.

Haron, S., \& Shanmugam, B. (1995). Effects of Rate of Profits on Islamic Bank's Deposits: A Note. Journal of Islamic Bank and Finance, 12, 18 - 28.

Hubbard, R. G. (2007). Money, The Financial System, and The Economy (6 ed.). Boston: Addison Wesley.

Kaleem, A., \& Isa, M. M. (2003). Causal Relationship Between Islamic and Conventional Banking Instrument in Malaysia. International Journal of Islamic and Financial Services, 4.

Kuncoro, M., \& Suhardjono. (2011). Manajemen Perbankan: Teori dan Aplikasi. Yogyakarta: BPFE.

Latumerissa, J. R. (2012). Bank dan lembaga Keuangan Lain. Jakarta: Salemba Empat.

Mahmoudi, H., Aslani, A., \& Hassanzadeh, M. (2013). The Factors Affecting The Amount of Banking Deposits at Ansar Bank Branches in Ardabil Province. International Journal of Management Research and Review, 3(9).

Mishkin, F. S. (2007). The Economics of Money Banking and Financial Market (8 ed.). Boston: Pearson Education Inc.

Muhammad. (2004). Manajemen Dana Bank Syariah (1 ed.). Yogyakarta: Ekonisia.

Pindyck, R. S., \& Rubinfeld, D. L. (2005). Microeconomics (6 ed.). New Jersey: Pearson Edcuation Inc. 
Rachmawati, E., \& Syamsulhakim, E. (2004). Factors Affecting Mudaraba Deposits in Indonesia. 2nd International Islamic Banking and Finance Conference. Bandung: Department of Economics and Development Studies, Universitas Padjajaran.

Rahmah, N. (2004). Hubungan Kausalitas Granger antara Tingkat Imbal Hasil Simpanan pada Bank Syariah dengan Suku Bunga Simpanan pada Bank Konvensional (Studi Kasus Bank Muamalat Indonesia dan Bank Syariah Mandiri). Depok, Jawa Barat, Indonesia: Universitas Indonesia.

Rose, P. S., \& Hudgins, S. C. (2013). Bank Management \& Financial Services (9 ed.). New York: Mc Graw Hill.

Siamat, D. (2005). Manajemen Lembaga Keuangan: Kebijakan Moneter dan Perbankan (5 ed.). Jakarta: Lembaga Penerbit Fakultas Ekonomi Universitas Indonesia.

Tim Bank Indonesia. (2014). Outlook Perbankan Syariah. Jakarta: Bank Indonesia. 